who lives in a city (100\%), has a higher education (79.3\%), is a civil servant $(82.8 \%)$, is not married $(68.9 \%)$, has no dependent minor children (55.2\%), has not been convicted $(100 \%)$ and has committed a crime alone $(82.8 \%)$. Thus, the above-mentioned elements of the criminological profile of the person who committed the disclosure of a state secret will help the operational staff to form an idea of the quota of people who may be prone to committing this type of crime. In addition, the use of a typical profile of such people will narrow the search for factual data on intelligence and subversive activities of foreign states special services and promote the interests of criminal justice, as well as obtaining the information in the interests of citizens, society and the state.

Keywords: national security, disclosure of state secrets, State Border Guard Service of Ukraine, the criminological profile, the criminal, the signs of a criminal, the Unified State Register of Court Decisions of Ukraine.

\title{
DOI: 10.33766/2524-0323.93.315-325
}

УДК 351.863:351.74 (477)

Шевчук О. О., кандидат юридичних наук, доцент, доцент кафедри економічної безпеки та фінансових розслідувань Національної академії внутрішніх справ (м. Київ, Україна) e-mail: alexosvita@ukr.net ORCID iD: https:/ / orcid.org/0000-0002-5513-6517

Марчевський С. В., кандидат юридичних наук, доцент кафедри економічної безпеки та фінансових розслідувань Національної академї внутрішніх справ (м. Київ, Україна) e-mail: marik1984@ukr.net ORCID iD: https:/ / orcid.org/0000-0002-3623-4461

\section{ЗАБЕЗПЕЧЕННЯ ЕКОНОМІЧНОЇ БЕЗПЕКИ ДЕРЖАВИ ОРГАНАМИ НАЦОНАЛЬНОЇ ПОЛІЩЇ УКРАЇНИ}

Стаття присвячена з'ясуванню ролі органів Національної поліції України в забезпеченні економічної безпеки держави.

У публікації викладено погляди науковців щодо визначення поняття економічної безпеки держави та участі Національної поліції України в ії забезпеченні.

Зауважено, що всі органи і підрозділи Національної поліції України опосередковано забезпечують економічну безпеку держави, а Департамент стратегічних розслідувань безпосередньо протидіс економічним (фінансовим) загрозам у нашій країні.

Ключові слова: національна безпека, економічна безпека, Національна поліція України, Департамент стратегічних розслідувань, Стратегія національної безпеки, корупщія.

Постановка проблеми. Усі органи державної влади мають турбуватися одним із першочергових завдань - забезпеченням Національної безпеки держави. Економічна безпека, будучи складовою національної безпеки, на сьогодні піддається чи не найбільшому внутрішньому та зовнішньому впливу, який поступово погіршує стан економіки України. За інформацією Національного банку України щодо результатів дослідження української економіки, 846 млрд. гривень або

(С) Шевчук О. О.,

Марчевський С. В., 2021 
23,8 \% від офіційного ВВП за 2018 рік перебуває в тіні, з них: 19,7 \% ВВП (702 млрд. грн) становить готівкова тіньова економіка, 4,1% ВВП (144 млрд грн) - домашне виробництво товарів для власного кінцевого використання, тобто негрошова тіньова економіка [1]. Така ситуація викликає занепокоєння і вкотре нагадує суб'єктам забезпечення економічної безпеки держави про необхідність ефективного здійснення своїх функцій.

Одним із ключових суб'єктів, що забезпечує економічну безпеку держави, є Національна поліція України, яка в межах своїх повноважень виконує завдання, спрямовані на захист економічного стану країни.

Аналіз останніх досліджень і публікацій. Окремі аспекти проблематики забезпечення економічної безпеки держави правоохоронними органами були висвітлені в роботах Н. С. Андрієнко, О. М. Бандурки, Р. С. Волощука, В. М. Гельман, К. М. Пасинчука, О. М. Резніка, В. В. Чернея, В. С. Чубань тощо.

Водночас, зважаючи на сучасний економічний стан в державі, не всі питання забезпечення економічної безпеки органами Національної поліції України знайшाи своє вирішення.

Формулювання цілей. Метою наукової статті є визначення ролі органів Національної поліції України в забезпеченні економічної безпеки держави на основі положень вітчизняного законодавства, що регулюють питання економічної безпеки держави, практики його застосування, а також наукових підходів провідних учених з означеної тематики.

Виклад основного матеріалу. Відповідно до пункту 9 частини 1 статті 1 Закону України «Про Національну безпеку України» від 21 червня 2018 року, національна безпека України - це захищеність державного суверенітету, територіальної цілісності, демократичного конституційного ладу та інших національних інтересів України від реальних та потенційних загроз. Цим правовим актом передбачено розроблення Стратегії національної безпеки України, яка є основою для підготовки всіх інших документів щодо планування у сферах національної безпеки і оборони. Реалізація Стратегії національної безпеки України здійснюється на основі національного оборонного, безпекового, економічного, інтелектуального потенціалу з використанням механізмів державно-приватного партнерства, а також із залученням міжнародної консультативної, фінансової, матеріально-технічної допомоги [2].

У пункті 66 Указу Президента України «Про рішення Ради національної безпеки і оборони України «Про Стратегію національної безпеки України»» від 14 вересня 2020 року наголошується, що ця Стратегія є основою для розроблення документів щодо планування у сферах національної безпеки і оборони, які визначатимуть шляхи та інструменти їі реалізації, серед яких визначена і Стратегія економічної безпеки [3].

На сьогодні, Стратегія економічної безпеки держави відсутня. Водночас, розроблено тї проєкт, який перебуває на етапі експертного обговорення [4].

3 огляду на передбачені в законодавстві положення, Україна, перебираючи досвід європейських країн, рухається в напрямку європейського політичного, еко- 
номічного, безпекового, правового простору задля набуття членства в Свропейському Союзі та в Організащіі Північноатлантичного договору. Такі кроки держави характеризують їі як правову, соціальну, демократичну та незалежну, яка має намір забезпечувати захист прав та свобод людини в державі та ії економічний добробут.

На думку А. Г. Чубенка, економічна безпека - це стан захищеності національної економіки, що характеризується здатністю до стабільного функціонування, розвитку, а також стійкістю до внутрішніх і зовнішніх загроз, зростанням конкурентоспроможності держави у світовому економічному середовищі [5, с. 99].

Своєю чергою, О. М. Рєзнік пропонує розглядати економічну безпеку держави як стан економіки та інститутів влади, за якого забезпечується гарантований захист національних інтересів, гармонійний, соціально-орієнтований розвиток країни в цілому, достатній економічний та оборонний потенціал навіть за найнесприятливіших варіантів розвитку внутрішніх та зовнішніх процесів [6, с. 345].

Попри представлені визначення економічної безпеки держави науковцями, подібний зміст цього поняття було закріплено в наказі Міністерства економічного розвитку і торгівлі України «Про затвердження Методичних рекомендацій щодо розрахунку рівня економічної безпеки України» від 29 жовтня 2013 року № 1277.

Відповідно до пункту 5 розділу 2 цього наказу, економічна безпека держави - це стан національної економіки, який дає змогу зберігати стійкість до внутрішніх та зовнішніх загроз, забезпечувати високу конкурентоспроможність у світовому економічному середовищі і характеризує здатність національної економіки до сталого та збалансованого зростання [7].

На наш погляд, незважаючи на те, що цей наказ носить інформаційний, рекомендаційний, роз' яснювальний характер та не є обов' язковим, представлене визначення можна взяти за основу.

Згідно зі статтею 12 Закону України «Про національну безпеку України», до складу органів, які здійснюють свої функції із забезпечення національної безпеки держави, входить Національна поліції України [2]. Національна поліція України (поліція) - це центральний орган виконавчої влади, який служить суспільству шляхом забезпечення охорони прав і свобод людини, протидії злочинності, підтримання публічної безпеки і порядку [8].

Доцільно зупинитися на позищії М. Ф. Криштановича, який вказав, що особливість діяльності Національної поліції України полягає в механізмі управлінської діяльності, який поділяється на організаційний, інституційний, нормативно-правовий механізм та механізм міжнародного співробітництва. Завдяки цим механізмам управління, Національна поліція України впливає на забезпечення економічної безпеки суб'єктів господарювання та гарантування внутрішньої безпеки держави та суспільства. Погоджуємося із думкою цього науковця, що мета організаційного механізму управлінської діяльності поліції полягає в застосуванні визначених законодавством принципів та методів, спрямованих на охорону основних об'єктів національної безпеки, у нашому випадку - економічної безпеки. Задля реалізації вказаної мети існують такі основні напрямки діяльності поліщії: адміністративна, профілактична, кримінально-процесуальна, оперативно-розшукова, охоронна та виконавча. Економічна безпека є однією з основних складових державної безпеки. 
Саме вона відображає причинно-наслідковий зв' язок між економічною міцщю держави, їі воєнно-економічним потенціалом та національною безпекою [9].

Нормативно-правовий механізм управлінської діяльності складається із норм, які відбиті в спеціальних правових документах, що регулюють основу економічної безпеки держави.

До таких правових документів слід віднести:

- Конституцію України;

- Закони України, зокрема: «Про Національну безпеку України» від 21.06.2018, «Про Раду національної безпеки і оборони України» від 05.03.1998, «Про запобігання корупщіï від 14.10.2014; «Про запобігання та протидію легалізації (відмиванню) доходів, одержаних злочинним шляхом, фінансуванню тероризму та фінансуванню розповсюдження зброї масового знищення» від 06.12.2019;

- у певних частинах - Цивільний, Цивільний процесуальний, Кримінальний, Кримінальний процесуальний, Господарський, Господарський процесуальний, Митний, Бюджетний кодекси України;

- Укази та Розпорядження Президента України (зокрема, Указ Президента України «Про рішення Ради національної безпеки і оборони України від 14 вересня 2020 року «Про Стратегію національної безпеки України»);

- Постанови та Розпорядження Кабінету Міністрів України.

Інституційний механізм управлінської діяльності поліції направлений на розроблення стратегії та методів реформування системи щодо забезпечення економічної безпеки суб'єктів господарювання, а саме на:

- реформування системи органів Національної поліції України;

- ліквідацію та реорганізацію елементів організаційної структури поліції для забезпечення економічної безпеки в цілому;

- взаємодію поліції з іншими правоохоронними органами державної влади щодо забезпечення економічної безпеки держави;

- співпрацю з громадськими організаціями;

- взаємодію поліції з органами місцевого самоврядування щодо забезпечення економічної безпеки суб'єктів господарювання на місцевому рівні [9].

Щодо механізму міжнародного співробітництва, то він направлений на виведення функціонування Національної поліції України на рівень міжнародних стандартів соціально-сервісної дії, а саме:

- правове забезпечення та інституційне співробітництво в рамках міжнародних організацій щодо забезпечення економічної безпеки суб'єктів господарювання;

- співпраця поліції з подібними структурами Свропейського Союзу щодо забезпечення економічної безпеки;

- правильне використання набутого та апробованого міжнародного досвіду щодо забезпечення економічної безпеки;

- налагодження ефективного інформаційного обміну між поліцією та суб'єктами міжнародного права та поглиблення процесу європейської інтеграції України щодо забезпечення національної безпеки держави [9].

Наказом Міністерства економічного розвитку і торгівлі України «Про затвердження Методичних рекомендацій щодо розрахунку рівня економічної безпеки 
України» від 29.10.2013 № 1277 передбачено складові економічної безпеки, якими є: виробнича, демографічна, енергетична, зовнішньоекономічна, інвестиційноінноваційна, макроекономічна, продовольча, соціальна, фінансова безпеки [7].

У проєкті «Стратегії економічної безпеки на період до 2025 року» закріплено умови та причини, які призвели до ситуації на сьогодні в кожній сфері, а також стратегічний курс державної політики, механізми тї реалізації та очікувані результати. Зокрема, визначено, що за підсумками 2019 року рівень фінансової безпеки зменшився на 4 в.п. (порівняно з 2018 роком) - до $42 \%$ - та на 3 в.п. - до $38 \%$ - за підсумками першого півріччя 2020 року (порівняно з рівнем у першому півріччі 2019 року) [4]. Такі показники не можуть свідчити про позитивність ситуації. Вони, певною мірою, відбивають і результат діяльності правоохоронних органів, у тому числі й органів Національної поліції України в забезпеченні фінансової безпеки.

Зі змісту Закону України «Про Національну поліцію» від 02 липня 2015 року вбачається, що функції та завдання органів і підрозділів поліції направлені на забезпечення внутрішньої безпеки держави. Зокрема, у законі закріплено обов'язок поліції протидіяти злочинності, що і вказує на те, що функції всіх їі органів та підрозділів направлені на забезпечення економічного (фінансового) захисту держави. Проте, не всі органи й підрозділи поліції наділені цими функціями, а тому вони здійснюють цей захист опосередковано, шляхом співпраці з уповноваженими на те органами й підрозділами (передають певні відомості чи матеріали тощо).

Своєю чергою, у Національній поліції України існує орган, який безпосередньо забезпечує економічну безпеку держави. На сьогодні таким органом є Департамент стратегічних розслідувань Національної поліції України (далі - ДСР) і відповідно його підрозділи.

Визначення ролі органів Національної поліції України в забезпеченні економічної безпеки держави неможливе без з'ясування ії адміністративно-правового статусу. Як зазначає Д. М. Ластович, під адміністративно-правовим статусом Національної поліції України потрібно розуміти визначене нормами адміністративного права його юридичне становище в механізмі держави та системі суспільних відносин [10, с. 74].

Досліджуючи адміністративно-правові засади діяльності правоохоронних органів із забезпечення фінансово-економічної безпеки України, О. М. Резнік визначив структуру адміністративно-правового статусу правоохоронних органів України як суб' єктів забезпечення фінансово-економічної безпеки держави, а саме:

1) мета, завдання та функції правоохоронних органів, що забезпечують фінансово-економічну безпеку Украӥни;

2) компетенція і повноваження правоохоронних органів, що забезпечують фінансово-економічну безпеку України;

3) організаційно-штатна структура правоохоронних органів, що забезпечують фінансово-економічну безпеку України;

4) юридичні гарантії та юридична відповідальність правоохоронних органів, що забезпечують фінансово-економічну безпеку України [11, с. 138]. 
Оскільки ДСР Національної поліції України є тим органом, який безпосередньо забезпечує економічну безпеку всередині країни, визначимо його ключові елементи структури адміністративно-правового статусу.

Департамент стратегічних розслідувань $є$ доволі «молодим» міжрегіональним територіальним органом Національної поліції України, який створений, фактично, на заміну Департаменту захисту економіки, що був ліквідований 2 вересня 2019 року. Відповідно до Наказу Національної поліщії України «Про затвердження Положення про Департамент стратегічних розслідувань Національної поліції України» від 23.10.2019 № 1077, ДСР - це міжрегіональний територіальний орган у складі кримінальної поліції Національної поліції України, який бере участь у реалізації державної політики з питань боротьби з організованою злочинністю та, згідно із законодавством України, здійснює оперативно-розшукову діяльність [12]. Метою діяльності ДСР Національної поліщії України є: усунення причин та умов, які сприяють виникненню та діяльності суспільно небезпечних організованих груп і злочинних організацій; усунення причин та умов виникнення та поширення корупщії; захист прав і свобод людини і громадянина та об'єктів права власності від протиправних посягань. Його завданнями є:

1) виявлення, припинення і попередження незаконної діяльності суспільно небезпечних організованих груп і злочинних організацій, у тому числі в органах державної влади та місцевого самоврядування, які впливають на криміногенну ситуацію в державі та в окремих їі регіонах;

2) здійснення заходів, спрямованих на координацію діяльності органів (підрозділів) поліції у сфері боротьби з тероризмом відповідно до компетенції, визначеної законодавством України;

3) протидія корупщії серед посадових осіб, на яких поширюється дія Закону України «Про запобігання корупщіі», вжиття заходів з метою виявлення корупційних правопорушень і правопорушень, пов'язаних із корупщією, та їх припинення відповідно до законодавства України;

4) здійснення оперативно-розшукової діяльності, спрямованої на здобуття інформації про криміногенні процеси в злочинному середовищі, пов'язані з протиправною діяльністю окремих осіб та злочинних угруповань, схеми легалізаціі (відмивання) доходів, одержаних злочинним шляхом;

5) організація та здійснення відповідно до законодавства України заходів захисту працівників ДСР, інших органів та підрозділів Національної поліції України, забезпечення безпеки учасників кримінального судочинства, членів їх сімей та близьких родичів цих осіб [12].

Оскільки одним із завдань цього органу є протидія корупщіі, то він забезпечує економічну безпеку держави, а саме їі складову - фінансову безпеку.

Щодо функцій цього органу, то в цій частині відомчого правового акту міститься службова інформація, яка не є публічною.

Варто погодитись із І. О. Ревак, що суб'єкти економічної безпеки повинні здійснювати свою діяльність на основі визначеної стратегії та тактики. Стратегія економічної безпеки має відповідати інтересам та пріоритетам суспільства і дер- 
жави й бути спрямованою на досягнення встановлених цілей. Стратегія передбачає чітке обгрунтування цілей та завдань, розробку довгострокової політики держави щодо виявлення, попередження та усунення загроз економічній безпеці держави. Окрім цього, стратегія повинна охоплювати комплекс заходів превентивного характеру, що здійснюється всіма суб'єктами безпеки, та систему заходів негайного реагування в разі миттєвої реалізації загроз [13, с. 68].

Позитивним кроком діяльності Міністерства внутрішніх справ України (далі - МВС України) було запровадження «Стратегії розвитку органів системи Міністерства внутрішніх справ на період до 2020 року» від 15 листопада 2017 року, у якій визначено, що роль МВС України полягає у створенні умов для розвитку безпечного середовища життєдіяльності як основи безпеки на території України, а також сучасної системи внутрішньої безпеки як фактора стримування збройної агресії Російської Федерації [14].

Стратегія передбачає, що одним із стратегічних пріоритетів розвитку органів МВС України є подолання одного із таких викликів як складна криміногенна ситуація в державі, високий рівень корупції та організованої злочинності, економічна нестабільність та поява нових типів загроз і злочинів унаслідок збройної агресії з боку Російської Федерації [14]. Це свідчить про те, що всі органи МВС України направлені забезпечувати економічну безпеку держави.

Невдовзі, після схвалення «Стратегії розвитку органів системи Міністерства внутрішніх справ на період до 2020 року», органи Національної поліції України 12 квітня 2019 року представили проєкт «Стратегії розвитку Національної поліщії на період до 2023 року». У вказаному проєкті передбачається, що в діяльності Національної поліції України мають місце корупційні ризики, які потребують уваги та вжиття відповідних заходів, що спрямовані на їх усунення. Також визначено, що однією із цілей стратегії є забезпечення реалізації заходів щодо запобігання та протидії корупцийним правопорушенням у сфері надання поліцейських послуг [15]. На сьогодні цей проєкт так і не прийнятий.

Слушно також зауважити, що Стратегія національної безпеки визначає актуальні загрози національній безпеці України. Водночас, $з$ огляду на ситуацію, яка склалась на сьогодні, загрози, які направленні на знищення економіки України, є актуальними загрозами національній безпеці нашої держави. Водночас, розроблення Стратегії економічної безпеки не є обов' язковим заходом держави, про що свідчить: Закон України «Про національну безпеку України», який не передбачає iї розроблення; Указ Президента України від 14 вересня 2020 року «Про рішення Ради національної безпеки і оборони України «Про Стратегію національної безпеки України»», у якому визначена лише норма, що Стратегія національної безпеки є основою для розроблення інших документів планування, зокрема Стратегії економічної безпеки, тобто яка не $є$ імперативною; наказ Міністерства економічного розвитку і торгівлі України «Про затвердження Методичних рекомендацій щодо розрахунку рівня економічної безпеки України» № 1277, що має рекомендаційний характер і не є обов' язковим.

Висновки. Таким чином, вважаємо за необхідне: 
1. Передбачити Стратегію економічної безпеки у Законі України «Про національну безпеку України», що визначить обов'язковий характер їі розроблення уповноваженими органами та сприятиме якісному виконанню передбачених у ній заходів задля ефективного забезпечення економічної безпеки держави.

2. Схвалити Стратегію розвитку Національної поліції України на період до 2023 року, що допоможе систематизувати всі загрози національній безпеці, зокрема економічній, у цьому документі, та запровадити шляхом прогнозування ті механізми, які можуть їм запобігти й усунути їх.

Отже, роль органів Національної поліції України в забезпеченні економічної безпеки держави полягає в тому, що вона направлена на протидію внутрішнім загрозам держави, які впливають на стан економіки. 3 огляду на завдання поліції, вона зобов' язана протидіяти злочинності, а це означає, що всі їі органи і підрозділи опосередковано забезпечують економічну безпеку держави. Своєю чергою, ключовим органом Національної поліції України, який безпосередньо протидіє економічним (фінансовим) загрозам у нашій державі, є Департамент стратегічних розслідувань.

\section{Використані джерела:}

1. Тіньова економіка в Україні. Офіційний сайт Національного банку Украӥни. URL : https://bank.gov.ua/ua/news/all/doslidjennya-tinovoyi-ekonomiki-v-ukrayini-mayje-ch vert-vvp--abo-846-mlrd-griven--perebuvaye-v-tini. (дата звернен ня: 18.02.2021).

2. Про національну безпеку України : Закон України від 21 червня 2018 р. № 2469VIII. Редакція від: 24.10.2020. URL : https://zakon.rada.gov.ua/laws/show/2469-19\#Text. (дата звернення: 18.02.2021).

3. Про рішення Ради національної безпеки і оборони України про Стратегію національної безпеки України: затв. Указом Президента України від 14.09.2020 р. № 392/ 2020. URL : https:/ / zakon.rada.gov.ua/laws/show/392/2020\#Text. (дата звернення: 18.02.2021).

4. Про рішення Ради національної безпеки і оборони України про Стратегію економічної безпеки України на період до 2025 року: проєкт Указу Президента України від 2021 p. URL : https://www.kmu.gov.ua/news/minekono miki-strategiya-ekonomichnoyibezpeki-fundament-dlya-zabezpechennya-ekonomich nogo-suverenitetu-ukrayini. (дата звернення: 18.02.2021).

5. Чубенко А. Г. Теоретико-правовий аспект забезпечення економічної безпеки. Науковий вісник Національної академії внутрішніх справ. 2014. № 3. С. 88-101.

6. Резнік О. М. Економічна безпека - європейський досвід запобігання та розкриття економічних злочинів. Діяльність органів публічної влади щодо забезпечення стабільності та безпеки суспільства : матеріали Міжнародної науково-практичної конференції (м. Суми, 21-22 трав. 2015 р.). Суми : СумДУ, 2015. С. 345-348.

7. Про затвердження Методичних рекомендацій щодо розрахунку рівня економічної безпеки України: наказ М-ва економічного розвитку і торгівлі України від 29.10.2013 р. № 1277. URL : https:/ /zakon.rada.gov.ua/rada/show/ v1277731-13\#Tехt. (да та звернення: 18.02.2021).

8. Про Національну поліцію: Закон України від 02.07.2015 р. № 580-VIII. Редакція від: 01.01.2021. URL : https:/ / zakon.rada.gov.ua/laws/show/580-19\#Text. (дата звернення: 18.02.2021). 
9. Криштанович М. Ф. Роль поліції в системі забезпечення економічної безпеки суб' єктів господарювання. Ефрективна економіка. 2017. Вип. № 7. URL : http:/ / www.econo my.nayka.com.ua/?op=1\&z=5678. (дата звернення: 18.02.2021).

10. Ластович Д. Поняття адміністративно-правового статусу поліції як суб'єкта надання поліцейських послуг. Наше право. 2015. № 6. С. 71-75.

11. Резнік О. М. Адміністративно-правові засади діяльності правоохоронних органів із забезпечення фінансово-економічної безпеки України : дис. ... д-ра юрид. наук. Суми : СумДУ, 2019. 509 с.

12. Про затвердження Положення про Департамент стратегічних розслідувань На ціональної поліції України: наказ Нац. поліції України від 23.10.2019 № 1077 (у ред. нака зу від 12 травня 2020 р.). URL : http:/ / tranzit.ltd.ua/nakaz/. (дата звернення: 18.02. 2021).

13. Ревак О. І. Інтелектуальний потенціал у системі економічної безпеки України: дис. ... Д-ра. екон. наук. Львів : Львів. нац. ун-т ім. І. Франка, 2016. 474 с.

14. Про схвалення Стратегії розвитку органів системи Міністерства внутрішніх справ на період до 2020 року: розпорядження Кабінету Міністрів України від 15.11.2017 p. № 1023-p. URL : https://zakon.rada.gov.ua/laws/show/ 1023-2017-p\# n9. (дата звернення: 18.02.2021).

15. Про схвалення Стратегії розвитку Національної поліції на період до 2023 року: проєкт розпорядження Кабінету Міністрів України. URL : https://www.npu.gov.ua/as sets/userfiles/files/proektnpa/2019.04.08_Strategiya_NPU_do_2023.pdf. (дата звернен-ня: 18.02.2021).

\section{References:}

1. Tinova ekonomika v Ukraini. Ofitsiinyi sait "Natsionalnoho banku Ukrainy", Official site "The National Bank of Ukraine". N. d. N. p. URL : https://bank.gov.ua/ua/news/all/dosli djen nya-tinovoyi-ekonomiki-v-ukrayini-mayje-chvert-vvp--abo-846-mlrd-griven-perebuva ye-vtini. [in Ukrainian].

2. Pro natsionalnu bezpeku Ukrainy : Zakon Ukrainy vid 21 chervnia 2018 r. No. 2469-VIII. Redaktsiia vid: 24.10.2020. (2020) N. p. URL: https://zakon.rada. gov.ua/laws/show/246919\#Text. [in Ukrainian].

3. Pro rishennia Rady natsionalnoi bezpeky i oborony Ukrainy pro Stratehiiu natsionalnoi bezpeky Ukrainy: zatv. Ukazom Prezydenta Ukrainy vid 14.09.2020 r. No. 392/2020. (2020) N. p. URL : https://zakon.rada.gov.ua/laws/show/392/2020 \#Text. [in Ukrainian].

4. Pro rishennia Rady natsionalnoi bezpeky i oborony Ukrainy pro Stratehiiu eko nomi chnoi bezpeky Ukrainy na period do 2025 roku: proiekt Ukazu Prezydenta Ukrainy vid 2021 r. (2021) N. p. URL : https://www.kmu.gov.ua/news/minekonomiki-strategiya-ekono michnoyibezpeki-fundament-dlya-zabezpechennya-ekonomichnogo-suverenitetu-ukrayini. [in Ukrainian]

5. Chubenko, A. H. (2014). Teoretyko-pravovyi aspekt zabezpechennia ekonomichnoi bez peky. Naukoryi visnyk Natsionalnoi akademii vnutrishnikh sprav, Scientific Herald of National Aca demy of Internal Affairs - Scientific Bulletin of the National Academy of Internal Affairs, 3, 88-101. [in Uk rainian].

6. Rieznik, O. M. (2015). Ekonomichna bezpeka - yevropeiskyi dosvid zapobihannia ta rozkryttia ekonomichnykh zlochyniv. Diialnist orhaniv publichnoi vlady shchodo zabezpechennia stabi Inosti ta bezpeky suspilstva : materialy Mizhnarodnoi naukovo-praktychnoi konferentsii (m. Sumy, 21-22 trav. 2015 r.). - Activities of public authorities to ensure the stability and security of society: proceedings of the International Scientific and Practical Conference (c. Sumy, May 21-22, 2015), 345-348. Sumy: SumDU. [in Ukrainian].

7. Pro zatverdzhennia Metodychnykh rekomendatsii shchodo rozrakhunku rivnia eko nomichnoi bezpeky Ukrainy: nakaz M-va ekonomichnoho rozvytku i torhivli Ukrainy vid 29. 
10.2013 r. No 1277. (2013) N. p. URL : https://zakon.rada.gov.ua/rada/show/v1277731-13\# Text. [in Ukrainian].

8. Pro Natsionalnu politsiiu: Zakon Ukrainy vid 02.07 .2015 r. No 580-VIII. Redaktsiia vid: 01.01.2021. (2021) N. p. URL: https:/ / zakon.rada.gov.ua/laws/show/580-19\#Text. [in Ukrai nian].

9. Kryshtanovych, M. F. (2017). Rol politsii v systemi zabezpechennia ekonomichnoi bez peky sub'iektiv hospodariuvannia. Efektyona ekonomika, Efficient Economy - Efficient economy, issue 7. URL : http://www.economy.nayka.com.ua/? op=1\&z=5678. [in Ukrainian].

10. Lastovych, D. (2015). Poniattia administratyvno-pravovoho statusu politsii yak sub'iekta nadannia politseiskykh posluh. Nashe pravo - Our Law, 6, 71-75. [in Ukrainian].

11. Rieznik, O. M. (2019). Administratyvno-pravovi zasady diialnosti pravookhoronnykh orhaniv iz zabezpechennia finansovo-ekonomichnoi bezpeky Ukrainy, Extended abstract of Dok tor's thesis. Sumy :SumDU. [in Ukrainian].

12. Pro zatverdzhennia Polozhennia pro Departament stratehichnykh rozsliduvan Natsi onalnoi politsii Ukrainy: nakaz Nats. politsii Ukrainy vid 23.10.2019 № 1077 (u red. nakazu vid 12 travnia 2020 r.). (2020) UR L: http:/ / tranzit.ltd.ua/nakaz/. [in Ukrainian].

13. Revak, O. I. (2016). Intelektualnyi potentsial u systemi ekonomichnoi bezpeky Ukrainy. Extended abstract of Doktor's thesis. Lviv : Lviv. nats. un-t im. I. Franka. [in Ukrainian].

14. Pro skhvalennia Stratehii rozvytku orhaniv systemy Ministerstva vnutrishnikh sprav na period do 2020 roku: rozporiadzhennia Kabinetu Ministriv Ukrainy vid 15.11.2017 r. No 1023-r. (2017) N. p. URL: https://zakon.rada.gov.ua/ laws/show/1023-2017-p\#n9. [in Ukrainian].

15. Pro skhvalennia Stratehii rozvytku Natsionalnoi politsii na period do 2023 roku: proiekt rozporiadzhennia Kabinetu Ministriv Ukrainy. N. d. N. p. URL: https:/ / www. npu. gov. ua/assets/userfiles/files/proektnpa/2019.04.08_Strategiya_NPU_do_2023.pdf. [in Ukrainian].

Стаття надійшла до редколегіï 22.02.2021

Шевчук А. А., кандидат юридических наук, доцент, доцент кафедры экономической безопасности и финансовых расследований Национальной академии внутренних дел (2. Киев, Украина)

Марчевский С. В., кандидат юридических наук, доцент кафедры экономической безопасности и финансовых расследований Национальной академии внутренних дел (2. Киев, Украина)

\section{ОБЕСПЕЧЕНИЕ ЭКОНОМИЧЕСКОЙ БЕЗОПАСНОСТИ ГОСУДАРСТВА ОРГАНАМИ НАЦИОНАЛЬНОЙ ПОЛИЦИИ УКРАИНЫ}

Статья посвящена определению роли органов Национальной полиции Украины в обеспечении экономической безопасности государства.

В публикации представлены взгляды ученых относительно определения понятия экономической безопасности государства и участия Национальной полиции Украины в ее обеспечении. Также обращено внимание на то, что все органы и подразделения Национальной полиции Украины опосредованно обеспечивают экономическую безопасность государства, а Департамент стратегических расследований Национальной полиции Украины не-посредственно противодействует экономическим (финансовым) угрозам в нашем го-сударстве.

Ключевые слова: национальная безопасность, экономическая безопасность, Национальная полиция Украины, Департамент стратегических расследований, Стратегия национальной безопасности, коррупция. 
Shevchuk O., Candidate of Juridical Sciences, Associate Professor, Associate Professor of the Department of Economic Security and Financial Investigations of the National Academy of Internal Affairs (Kyiv, Ukraine)

Marcherskyi S., Candidate of Juridical Sciences, Associate Professor of the Department of Economic Security and Financial Investigations of the National Academy of Internal Affairs (Kyiv, Ukraine)

\section{ENSURING THE STATE ECONOMIC SECURITY BY THE AUTHORITIES OF NATIONAL POLICE OF UKRAINE}

The scientific article is devoted to clarifying the role of the National Police of Ukraine in ensuring the state economic security.

The article identifies the views of scholars on the definition of state economic security and the participation of the National Police of Ukraine in its ensuring. Statistical indicators of economic performance of Ukraine and relative indicators of the level of financial security are represented.

The view of scientists that the peculiarity of the role of National Police of Ukraine underlies the mechanism of management activity (organizational, institutional, legislative and international cooperation mechanism), through which the police influence ensuring the economic security of economic entities and guarantee the state and social internal security is supported.

It is highlighted that the state economic security includes a number of elements and is a component of national security. It is also emphasized that by ensuring the state economic security the National Police of Ukraine mainly counteracts threats to its financial component.

The paper reveals the importance of approving the Economic Security Strategy for the period up to 2025, theStrategy for the development of the system of the Ministry of Internal Affairs for the period up to 2020, the DevelopmentStrategy of the National Police of Ukraine for the period up to 2023.

The author came to the conclusion that the role of the National Police of Ukraine in ensuring the state economic security is that it is aimed at counteracting the internal threats of the state that affect the economic performance. Given the target of the police, it has a duty to combat crime, which means that all its bodies and units indirectly ensure the state economic security. It is established that the key body of the National Police of Ukraine, which directly counteracts economic (financial) threats in our country is the Department of Strategic Investigations.

Keywords: national security, economic security, National Police, Department of Strategic Investigations, National Security Strategy, corruption. 